\title{
The Usage of Social Media Instagram Towards Brand Awareness of Wyndham OPI Hotel Palembang During the Pandemic Era
}

\author{
Enos Julvirta ${ }^{1}$, Mustika Permatasari ${ }^{2 *}$, L. Suhairi ${ }^{3}$ \\ ${ }^{1,2,3}$ Palembang Polytechnic of Tourism \\ *Corresponding author. Email: mup@poltekpar-palembang.ac.id
}

\begin{abstract}
Indonesia is a country with a very dense population. Entering the era of information communication technology, everything moves faster, information and conversations can be carried out without being limited due to the rapid development of information communication technology. From a business perspective, marketing through social media has offered a variety of new opportunities for companies to promote their brands, products, and services. In the hospitality business, many hotels and restaurants have adapted social media marketing as one of their marketing tools for brand awareness. The use of digitalization is felt by the management of Wyndham Opi Hotel who plays an active role in promoting products and services using Instagram, Facebook or through the website. This research is quantitative, involving 100 respondents who were taken randomly as research samples. The data used are primary data obtained through questionnaires. Analyzer using Simple Linear Regression. The results of the study indicate that the use of Instagram social media has a significant effect on brand awareness at Wyndham Opi Hotel.
\end{abstract}

Keywords : social media, brand awareness.

\section{INTRODUCTION}

The existence of social media is like a magnet that is very useful for Indonesian social activities every day. Not to mention that its role is influenced by the rapid development of communication technology in this era of globalization. These changes will surely bring results that have a very significant impact in various ways. Society, economy, education, culture, tourism, and many more. Social media that ranks first is Facebook at 65.8 percent, then Ere Kapa is in second place at 42.3 percent, WhatsApp is in third place at 31.3 percent and Twitter is at 10 percent as the most frequently visited media. (Asosiasi Penyelenggara Jasa Internet Indonesia, n.d. $)^{[1]}$

One hotel that plays an active role in increasing tourist visits is Wyndham Opi Hotel Palembang, which is locasion in Banyuasin district. With the luxury of its facilities and complete facilities and infrastructure, this hotel makes a strategy to increase the number of room occupancy, especially in this pandemic era. (Langdon et al., 2018) ${ }^{[6]}$

The use of digitalization is felt by the management of Wyndham Opi Hotel who plays an active role in promoting products and services using Instagram, Facebook or through the website. It can be seen that Wyndham Opi Hotel Palembang has made many efforts to strengthen the brand, so it is hoped that these activities will be able to strengthen brand awareness to increase guest arrivals.

However, from the results of the pre-survey that have been submitted previously, it appears that there is a lack of information from social media obtained regarding brand awareness of guests who visit Wyndham Opi Hotel Palembang. Seeing this condition, this research is interested in conducting research with the title: "Use of Instagram Social Media Against Brand Awareness Whyndam Opi Hotel Palembang in the Pandemic Era. 


\section{LITERATURE REVIEW}

\subsection{Digital Marketing}

"Digital marketing is the application of the internet and related digital technologies in conjunction with traditional communications to to achieves marketing objectives.". This can be achieved to increase knowledge about consumers such as profiles, behavior, values, and loyalty levels, then integrate targeted communications and online services according to each individual needs (Digital Marketing: Strategy, Implementation \& Practice Dave Chaffey, Fiona Ellis-Chadwick - Google Buku, n.d. $)^{[3]}$

\subsection{Social Media}

Social media is a combination of 2 (two) words, namely social and media. Philip Wexler stated that social is the nature of every human individual. Social media is one of the products of the emergence of new media. In social media, every individual and group can interact with each other online via the internet. Social media is a site where people communicate with their friends they know in the real world or in cyberspace (Kato et al., 2011) ${ }^{[5]}$

Apart from the explanation of social media from (Kato et al., 2011) ${ }^{[5]}$ says that social media is used to communicate with friends, in the development of social networks, friends mean customers because the use of social media is not only used by individuals to socialize, but also by companies in socializing with customers to do business. marketing and to improve the company's image.

\subsection{Brand Awareness}

In the research related to marketing strategy, Karo use the brand as an indicator in mapping the market position, which is used to design a marketing strategy where the brand becomes the company's internal strength (Karo \& Hamonangan, 2021) ${ }^{[4]}$. It shows the importance of building a brand for both the product and the company. In general, brand awareness describes people's perceptions and reactions to a condition or event. Consciousness does not necessarily imply understanding as it is an abstract concept. Consciousness can be focused on internal states, such as instinctive feelings, or on external events such as sensory perception. Brand awareness is the ability of potential buyers to recognize and recall a brand as part of a particular product category. Brand awareness is created through brand development with the F.R.E.D (Familiarity, Relevance, Esteem, and
Difference) model. The most important concept of F.R.E.D is to make customer friendly with products and services. This concept shows how important it is for a brand to make customers familiar with the brand, value customers, and stand out from competitors by providing better quality, value and service. (Sharma et al., 2004 $)^{[11]}$

\section{RESEARCH METHODS}

This study uses a quantitative approach which aims to find relationships on theoretical variables that are applied through hypotheses or assumptions whose tests are based on processed numerical data using statistical methods. (Moleong, 2007) ${ }^{[6]}$

\subsection{Population and Sample}

Data collection activities are an important step to determine the characteristics of the population which are elements in the object of research. Population is a generalization area consisting of objects/subjects that have certain quantities and characteristics determined by the researcher to be studied and then draw conclusions. The population in this study are guests who stay at Wyndham Opi Hotel Palembang.

And for the sample in this study using probability sampling with the technique used is simple random sampling technique. According to (Murphy, $2013)^{[7]}$ is to define a simple random sampling technique is the taking of sample members from the population is done randomly without regard to the strata that exist in the population.

The sampling technique used in this study is probability sampling, one of the techniques used is simple random sampling technique. According to( Sugiyono ${ }^{[10]}$ is to define a simple random sampling technique is the taking of sample members from the population is done randomly without regard to the strata that exist in the population.

Collecting data in this study were interviews, questionnaires, observations as well as literature study. Testing Instruments of this research are:

\subsection{Validity Test}

According to (Sugiyono ${ }^{[10]}$, Validity shows the degree of accuracy between the data that actually occurs on the object and the data collected by researchers to find the validity of an item, we correlate the item score with the total of these items. If the coefficient between the items and the total items is equal to or above 0.3 then the item is declared valid, 
but if the correlation value is below 0.3 then the item is declared invalid.

Table 1. Validity Test Result

\begin{tabular}{|c|c|c|}
\hline $\begin{array}{r}\text { No } \\
\text { Item }\end{array}$ & $\begin{array}{l}\text { Corrected Item - } \\
\text { Total Correlation }\end{array}$ & Keterangan \\
\hline 1 & 0.575 & Valid \\
\hline 2 & 0.502 & Valid \\
\hline 3 & 0.366 & Valid \\
\hline 4 & 0.679 & Valid \\
\hline 5 & 0.646 & Valid \\
\hline 6 & 0.653 & Valid \\
\hline 7 & 0.613 & Valid \\
\hline 8 & 0.552 & Valid \\
\hline 9 & 0.562 & Valid \\
\hline 10 & 0.524 & Valid \\
\hline 11 & 0.528 & Valid \\
\hline 12 & 0.443 & Valid \\
\hline 13 & 0.372 & Valid \\
\hline 14 & 0.544 & Valid \\
\hline 15 & 0.622 & Valid \\
\hline 16 & 0.632 & Valid \\
\hline 17 & 0.622 & Valid \\
\hline 18 & 0.627 & Valid \\
\hline 19 & 0.429 & Valid \\
\hline 20 & 0.428 & Valid \\
\hline 21 & 0.475 & Valid \\
\hline 22 & 0.454 & Valid \\
\hline 23 & 0.545 & Valid \\
\hline 24 & 0.530 & Valid \\
\hline
\end{tabular}

Source: Processed by SPPS 24, (2021).

From the results of the calculation of each question item from each variable, it is found that the Corrected Item-Total Correlations value is greater than 0.3 which indicates that it is valid and there is no need for improvement or omission of indicators.

\subsection{Reliability Test}

The reliability test according to Sugiyono (2010: $354)^{[10]}$ is carried out to find out how far the measurement results remain consistent when two or more measurements are made of the same symptoms using the same measuring instrument. To see whether a measuring instrument is reliable or not, a statistical approach is used, namely through the reliability coefficient and if the reliability coefficient is greater than 0.60 then the overall statement is declared reliable.

The following are the results of calculations from the SPSS version 24.00 tool:
Table 2. Instagram Social Media Variable Reliability Test Results (X)

\begin{tabular}{|c|c|c|}
\hline $\begin{array}{c}\text { Cronbach's } \\
\text { Alpha }\end{array}$ & $\begin{array}{r}\text { N of } \\
\text { Items }\end{array}$ & Keterangan \\
\hline 0.800 & 13 & Reliabel \\
\hline
\end{tabular}

Source: Processed by SPPS 24, (2021).

Table 3. Brand Awareness Variable Reliability Test Results (Y)

\begin{tabular}{|c|c|c|}
\hline $\begin{array}{c}\text { Cronbach's } \\
\text { Alpha }\end{array}$ & $\begin{array}{c}\text { N } \\
\text { of } \\
\text { Items }\end{array}$ & Keterangan \\
\hline 0.749 & 11 & Reliabel \\
\hline
\end{tabular}

Source: Processed by SPPS 24, (2021).

Based on tables 2 and 3, it can be seen that the Instagram Social Media and Brand Awareness variables are reliable because both values are greater than the $\mathrm{r}$ table, which is 0.6 .

\subsection{Multicollinearity Test}

Multicollinearity test is a test carried out to ascertain whether in a regression model there is intercorrelation or collinearity between independent variables.

\subsection{Autocorrelation Test}

Autocorrelation test is a test carried out to ascertain whether in a regression model there is intercorrelation or collinearity between independent variables.

\subsection{Heteroscedasticity Test}

The next classic assumption test is the heteroscedasticity test, which is a test that assesses whether there is an inequality of variance from the residuals for all observations in the linear regression model. If the assumption of heteroscedasticity is not met, then the regression model is declared invalid as a predictive tool. This can be seen through the significance value (Sig.) $>0.05$, which means that there are no heteroscedasticity symptoms.

Based on the results of data processing carried out by the author, the results of the heteroscedasticity test obtained are as follows: 


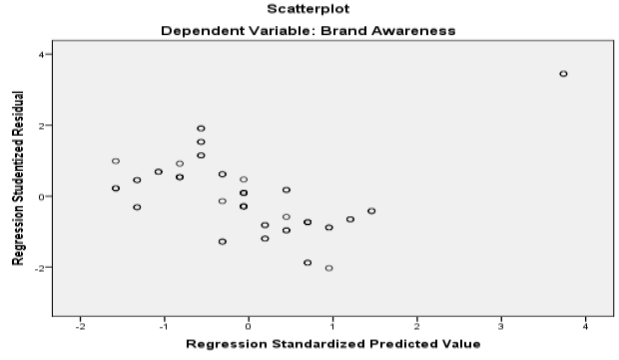

Figure 1. Heteroscedasticity Test Result

Source: Processed by SPSS 24, (2021).

In the picture above, it can be seen if the points contained in the graph do not occur heteroscedasticity in the regression model because the points spread do not form a pattern or are random which are above the number 0 and below the number 0 on the $\mathrm{Y}$ axis.

\subsection{Normality Test}

Normality test is a test carried out with the aim of assessing the distribution of data in a group of data or variables, whether the distribution of the data is normally distributed or not. Normality test is useful for determining the data that has been collected is normally distributed or taken from a normal population. Based on the results of data processing carried out by researchers, the results of the normality test obtained are as follows:

One-Sample Kolmogorov-Smirnov Test

\begin{tabular}{llr} 
& & $\begin{array}{r}\text { Unstandardiz } \\
\text { ed Residual }\end{array}$ \\
\hline N & Mean & 100 \\
\hline Normal Parameters & a,b & .0000000 \\
\cline { 2 - 3 } & Std. Deviation & 2.63457802 \\
\hline Most Extreme Differences & Absolute & .107 \\
\cline { 2 - 3 } & Positive & .107 \\
\cline { 2 - 3 } & Negative & -.068 \\
\hline Test Statistic & & .107 \\
\hline Asymp. Sig. (2-tailed) & & $.006^{\mathrm{c}}$ \\
\hline
\end{tabular}

Figure 2. Normality test result

Source: Processed by SPSS 24, (2021).

From the picture above, it can be proven that the residual data is normally distributed, this is because the value by Asymp Sig is 0.06 greater than 0.05 .

\subsection{Linearity Test}

The linearity test aims to determine whether two variables have a linear relationship or not significantly.
This test looks at how the variable (X) affects the variable (Y), whether the effect is directly proportional or inversely proportional. This test is usually used as a prerequisite in correlation analysis or linear regression.

\subsection{Hypothesis Test 3.9.1 Partial Test (T Test)}

The t-test difference test is used to test how far the influence of the independent variables used in this study individually in explaining the dependent variable partially.

\subsubsection{Simultaneous Test (F Test)}

Ghozali, Imam. (2011) ${ }^{\text {[2] }}$ The F test basically shows whether all independent variables or independent variables included in the model have a joint influence on the dependent variable or the dependent variable.

\section{RESEARCH RESULT AND DISCUSSION}

Based on the questionnaires distributed to guests staying at Wyndham Opi Hotel Palembang in September 2021, 100 questionnaires were collected which can be used as main information for hypothesis testing in this study.

Respondents in this study were guests who stayed at Wyndham Hotel Palembang. Questionnaires were distributed to 200 with 100 returned questionnaires. Of the 100 questionnaires that were successfully obtained, the respondent profiles were as follows:

\begin{tabular}{|c|c|}
\hline Profile Description & Total \\
\hline $\begin{array}{c}20-35 \text { years old } \\
36-45 \text { years old } \\
>45 \text { years old }\end{array}$ & $\begin{array}{l}20 \% \\
38 \% \\
42 \% \\
\end{array}$ \\
\hline $\begin{array}{l}\text { Profession } \\
\text { Government employees } / \text { BUMN } \\
\text { private employees } \\
\text { Entrepreneur }\end{array}$ & $\begin{array}{l}28 \% \\
32 \% \\
40 \% \\
\end{array}$ \\
\hline $\begin{array}{l}\text { Income } \\
\qquad \begin{array}{r}6.000 .000-10.000 .000 \\
>10.000 .000 \\
\text { lainnya }\end{array}\end{array}$ & $\begin{array}{l}27 \% \\
54 \% \\
19 \%\end{array}$ \\
\hline $\begin{array}{l}\text { Information about } \\
\text { Wyndham Hotel } \\
\qquad \begin{array}{r}\text { Media Online } \\
\text { Media Social } \\
\text { Family/realtion }\end{array}\end{array}$ & $\begin{array}{l}33 \% \\
42 \% \\
13 \% \\
12 \% \\
\end{array}$ \\
\hline
\end{tabular}




\begin{tabular}{|c|c|}
\hline \multicolumn{2}{|l|}{ Purpose of stay } \\
\hline Holiday & $48 \%$ \\
\hline Business needs & $37 \%$ \\
\hline Others & $15 \%$ \\
\hline \multicolumn{2}{|l|}{ Frequency of stays in } \\
\hline Wyndham Hotel & $52 \%$ \\
\hline First time & $34 \%$ \\
\hline 2- 5 times & $14 \%$ \\
\hline \multicolumn{2}{|l|}{$>5$ times } \\
\hline \multicolumn{2}{|l|}{$\begin{array}{l}\text { Instagram followers of } \\
\text { Wyndham Hotel }\end{array}$} \\
\hline Yes & $16 \%$ \\
\hline No & $84 \%$ \\
\hline
\end{tabular}

Table 4. Respondents Profile

Source: author's work, (2021).

In Table 4, it can be seen that the profile information of respondents in the age category shows that Wyndham Hotel's market share is guests over 45 years old. The type of work is dominated by entrepreneurs with a large amount of income above Rp. 10,000,000,-. Knowing information about Wyndham Opi Hotel Palembang through online media and having the purpose of staying, namely for a vacation. The guests who stay are guests who have just come to Wyndham Opi Hotel for the first time.

Based on the results of data processing that has been carried out for simple linear regression analysis, it is tested in the following table:

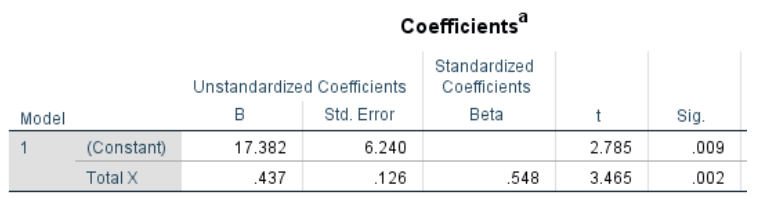

Figure 3. Simple Linear Regression Equation Source: Processed by SPSS 24, (2021).

Based on the picture above, the authors obtain a simple linear regression equation, as follows: $\mathrm{Y}=$ $17,382+0.437 \mathrm{X}$.

The above equation can be interpreted as follows: $\mathrm{a}=17,382$, meaning that if the application of social media Instagram is zero (0), then the brand awareness variable will still be worth 17,382 . $b=$ 0.437 , meaning that if the application of Instagram social media increases by one unit, then brand awareness will increase by 0.437 .

\subsection{Coefficient of Determination}

According to Ghozali, Imam. (2011). ${ }^{[2]}$ coefficient of determination (R2) is used to determine the ability of a paradigm in explaining the variation of the dependent variable, the value in the coefficient of determination is between 0 and 1 . The coefficient value is close to one which means that the independent variable provides almost all the information needed in estimate the variation of the dependent variable. If the value of $\mathrm{R} 2$ is small, it can be interpreted that the capability of the independent variable to explain the variation of the variable is very limited. Based on the results of data processing that has been carried out by researchers, it is found that the coefficient of determination obtained is as follows:

\begin{tabular}{ll|r|r|r}
\multicolumn{7}{c}{ Model Summary } \\
Model & R & R Square & $\begin{array}{c}\text { Adjusted R } \\
\text { Square }\end{array}$ & $\begin{array}{c}\text { Std. Error of } \\
\text { the Estimate }\end{array}$ \\
\hline 1 & $.504^{\text {a }}$ & .254 & .246 & 2.64799 \\
\hline
\end{tabular}

Figure 4. Coefficient of determination Source: Processed by SPSS 24, (2021).

Based on the picture above, it can be seen that the $\mathrm{R}$ result is 0.504 , then the coefficient of determination is calculated $0.504 \times 100=25.4 \%$ (Rsquare), this shows that $25.4 \%$ of the contribution of the influence of the application of Instagram social media on brand awareness, and the remaining 74.6\% is the influence of other variables not examined.

\subsection{Hypothesis}

(Sugiyono 2013) ${ }^{[10]}$ explained that the t-test was used with the aim of seeing the level of significance of the influence of each independent variable $(\mathrm{X})$ on the related variable (Y) with an estimate that the other independent variables $(\mathrm{X})$ did not change. The criteria used are as follows:

- Ho is accepted and H1 is rejected, if the value of $\mathrm{t}$ count $<\mathrm{t}$ table or $\operatorname{sig}>0.05$

- Ho is rejected and H1 is accepted, if the value of $t$ count $>\mathrm{t}$ table or sig $<0.05$

Based on the results of data processing carried out by the author, the results of the t test are obtained, which are obtained as follows:

\begin{tabular}{|c|c|c|c|c|c|c|}
\hline \multirow[b]{2}{*}{ Model } & & \multicolumn{2}{|c|}{ Unstandardized Coefficients } & \multirow{2}{*}{$\begin{array}{c}\text { Standardized } \\
\text { Coefficients } \\
\text { Beta }\end{array}$} & \multirow[b]{2}{*}{$t$} & \multirow[b]{2}{*}{ Sig. } \\
\hline & & B & Std. Error & & & \\
\hline \multirow[t]{2}{*}{1} & (Constant) & 17.382 & 6.240 & & 2.785 & .009 \\
\hline & Total X & .437 & .126 & .548 & 3.465 & .002 \\
\hline
\end{tabular}

Figure 5. Hypothesis Test Result (T Test)

Source: Processed by SPSS 24, (2021).

In the picture above testing the hypothesis, it can be seen that the application of social media has a significant effect on brand awareness, this is because the result of the calculated t value is 3.465 with a 
significance of 0.002 , and for the $t$ table in the $t$ distribution table that $=0.05, \mathrm{df}=\mathrm{nk}=100-2=98$ the result is 1,984 . Based on the value above, it can be seen that the t-count value obtained by the social media application variable is greater than the table value $(3.465>1.984)$, then $\mathrm{Ho}$ is rejected and $\mathrm{H} 1$ is accepted.

\section{CONCLUSION}

Based on data processing conducted by researchers, it can be concluded:

1. The application of Instagram Social Media carried out by Wyndham Opi Hotel Palembang from 13 question indicators given to guests that:

- For context, 100 respondents answered 59\% agreed that Wyndham Opi Hotel Palembang's Instagram social media had an attractive design, from 100 respondents answered 58\% agreed that Wyndham Opi Hotel Palembang's Instagram social media had interesting content and from 100 respondents answered $91 \%$ agree that Wyndham Opi Hotel Palembang's Instagram social media has an interesting caption/upload.

- For communication, from 100 respondents answered $57 \%$ agreed that it was easy for guests to get information about products at Wyndham Opi Hotel Palembang, from 100 respondents answered 55 agreed that there was complete information from uploaded content about Wyndham Opi Hotel Palembang, from 100 respondents answered $72 \%$ agreed that there was a response in replying to messages or comments about Wyndham Opi Hotel Palembang, and out of 100 respondents answered 58\% were hesitant to give a like on Wyndham Opi Hotel Palembang's Instagram.

- For collaboration, from 100 respondents answered that $63 \%$ agreed that guests understand the content uploaded by Wyndham Opi Hotel Palembang, and from 100 respondents answered that $55 \%$ were hesitant in responding to uploads posted by Wyndham Opi Hotel Palembang.

- For connections, 100 respondents answered that $58 \%$ agreed to trust the content uploaded by Wyndham Opi Hotel Palembang, 69\% agreed that there was a good and polite response to information by Wyndham Opi Hotel Palembang, $67 \%$ agreed to provide interactive information by Wyndham Opi Hotel Palembang and 53\% agree that the information provided by Wyndham Opi Hotel Palembang is useful.
2. Brand awareness of Wyndham Opi Hotel Palembang which has been filled out by 100 respondents as follows:

- For Unware of Brand, out of 100 respondents answered $78 \%$ doubtful in knowing Wyndham Opi Hotel Palembang, out of 100 respondents answered $75 \%$ doubtful in knowing Wyndham Opi Hotel Palembang products

- For brand recognition, 100 respondents answered that $48 \%$ were hesitant in responding to Wyndham Opi Hotel Palembang's posts, from 100 respondents answered $61 \%$ were hesitant in communicating about Wyndham Opi Hotel Palembang's posts, from 100 respondents answered 52\% agreed that influencers, endorsers or brand ambassadors are in accordance with the concept offered and from 100 respondents answered $70 \%$ agreed in understanding the promotions offered by Wyndham Opi Hotel Palembang through Instagram.

- For brand recall, 100 respondents answered $79 \%$ agreed that uploads or post feeds attract guests' attention and encourage the desire to buy the products offered, from 100 respondents answered $87 \%$ agreed that the information obtained from Instagram posts was in accordance with the wishes, from 100 respondents answered $48 \%$ agreed that respondents know the characteristics/logo of Wyndham Opi Hotel and from 100 respondents answered $56 \%$ were hesitant in remembering the Wyndham Opi Hotel Palembang brand.

- For top of mind, from 100 respondents answered that $52 \%$ agreed that the name of Wyndham Opi Hotel Palembang appears in the minds of respondents.

3. Use of social media Instagram on Brand Awareness Wyndham Opi Hotel Palembang In the Pandemic Era seen from the regression coefficient value of 0.437 indicating that there is a significant partial influence of the variable use of social media on brand awareness, which means the higher the value of social media use, the higher also the value of brand awareness positively. The value of the correlation coefficient $(\mathrm{R})$ of 0.504 is used to calculate the value of the coefficient of determination. The result of the coefficient of determination is 0.254 which means that the application of social media to brand awareness is $25.4 \%$ while the remaining $74.6 \%$ is influenced by other variables. 


\section{SUGGESTION}

Based on the conclusions obtained in this study, the following suggestions are proposed:

1. In the variables of social media use, there are indicators, namely communication and collaboration who answer doubts about likes to Wyndham Opi Hotel Palembang's posts and also in providing responses, the suggestion is to upload content in the form of interesting photos during prime time. Time at rest and at the end of the activity. Meanwhile, cooperation with sponsored advertising can be carried out to attract market share in terms of age, gender and hobbies.

2. In the brand awareness variable, there are indicators of unware of brand and brand recognition which answer in doubt, so the advice from researchers is that because the market share of Wyndham Opi Hotel Palembang is clear, it is better to focus on what they want. By cooperating with Banks, Shopping Centers and so on.

3. This research is limited to the use of social media on brand awareness at Wyndham Opi Hotel Palembang. So further research is needed in the development of research variables to support tourism growth, especially in Banyu Asin Regency.

\section{AUTHOR'S CONTRIBUTIONS}

Enos Julvirta: Performed Research, lead author, co Analyzed Data. Mustika Permatasari: Corresponding authors, analyzed data, co-author. L. Suhairi Hazisma: Co-authors, research city survey.

\section{ACKNOWNLEDGMENTS}

Special thank you to management's Wyndham Opi Hotel Palembang and participants in the research location.

\section{REFERENCES}

[1] Asosiasi Penyelenggara Jasa Internet Indonesia. (n.d.). Retrieved December 10, 2021, from https://apjii.or.id/

[2] DAFTAR PUSTAKA. Ghozali, Imam. (2011). Aplikasi Analisis Multivariate dengan Program IBM SPSS 19. Universitas Diponegoro: Semarang - PDF Free Download. (n.d.). Retrieved December 10, 2021, from https://adoc.pub/daftar-pustaka-ghozali-imam2011-aplikasi-analisis-multivari.html
[3] Digital Marketing: Strategy, Implementation \& Practice - Dave Chaffey, Fiona Ellis-Chadwick Google Buku. (n.d.). Retrieved December 10, 2021, from https://books.google.co.id/books?hl=id\&lr=\&id=

1yGDwAAQBAJ\&oi=fnd\&pg $=$ PT17\&dq $=($ Chaf fey+and+Chadwick,+2016:11)\&ots=XiSt4PmQ6 0\&sig=MzH_8z-

Mo_bgp16MnvONPmGGb2I\&redir_esc=y\#v=o nepage $\& \mathrm{q}=($ Chaffey and Chadwick $\% 2 \mathrm{C}$ $2016 \% 3 \mathrm{~A} 11) \& \mathrm{f}=$ false

[4] Karo, P. K., \& Hamonangan, S. (2021). Analisis Strategi Pemasaran Restoran Menghadapi Masa Pandemi Covid 19 Di Kota Pagar Alam. Jurnal Sains Sosio Humaniora, 5(1). https://doi.org/10.22437/jssh.v5i1.14152

[5] Kato, M. T., Hannas, A. R., Leite, A. L., Bolanho, A., Zarella, B. L., Santos, J., Carrilho, M., Tjäderhane, L., \& Buzalaf, M. A. R. (2011). Activity of Matrix Metalloproteinases in Bovine versus Human Dentine. Caries Research, 45(5), 429-434. https://doi.org/10.1159/000330525

[6] Langdon, R. J., Yousefi, P. D., Relton, C. L., \& Suderman, M. J. (2018). PENGARUH SOCIAL MEDIA MARKETING, BRAND AWARENESS TERHADAP KEPUTUSAN PEMBELIAN DENGAN MINAT BELI SEBAGAI VARIABEL INTERVENING PADA J.CO DONUTS \& COFFEE SEMARANG. Jurnal Ilmu Administrasi Bisnis, 7(3), 152-159. https://doi.org/10.2/JQUERY.MIN.JS

[7] Moleong, L. J. (2007). Metodologi penelitian kualitatif edisi revisi. http://library.stik-ptik.ac.id

[8] Murphy, P. (2013). Tourism: A Community Approach (RLE Tourism). Tourism: A Community Approach (RLE Tourism). https://doi.org/10.4324/9780203068533

[9] Pengaruh Social Media Marketing Terhadap Brand Awareness Pada E-Commerce Hijup | Salamah | Konferensi Riset Nasional Ekonomi Manajemen dan Akuntansi. (n.d.). Retrieved December 10, 2021, from https://conference.upnvj.ac.id/index.php/korelasi /article/view/1189

[10] Prof. Dr. sugiyono - Google Scholar. (n.d.). 
Retrieved December 10, 2021, from https://scholar.google.com/citations?user=uUIIuj UAAAAJ\&hl=en

[11] Sharma, R. A., Euden, S. A., Platton, S. L., Cooke, D. N., Shafayat, A., Hewitt, H. R., Marczylo, T. H., Morgan, B., Hemingway, D., Plummer, S. M., Pirmohamed, M., Gescher, A. J., \& Steward, W. P. (2004). Phase I Clinical Trial of Oral Curcumin: Biomarkers of Systemic Activity and Compliance.

[12] The Social Media Marketing Book - Dan Zarrella - Google Buku. (n.d.). Retrieved December 10, 2021, from https://books.google.co.id/books?hl=id\&lr=\&id= chd3yfExXMEC\&oi=fnd\&pg=PR4\&dq=Zarella, + D+(2011).+The+Social+Media+Marketing+Bo ok.+Sebastopol:+"Reilly+media,+Inc.\&ots $=\mathrm{u} 8 \mathrm{~K}$ 9oWw0Y0\&sig=5OcZIKGgGPkN-

IlDeDVXQ0HM6B8\&redir_esc=y\#v=onepage $\&$ $\mathrm{q} \& \mathrm{f}=$ false

[13] (Pengaruh Social Media Marketing Terhadap Brand Awareness Pada E-Commerce Hijup | Salamah | Konferensi Riset Nasional Ekonomi Manajemen Dan Akuntansi, n.d.)

[14] The Social Media Marketing Book - Dan Zarrella - Google Buku, n.d.) 